Global Conferences Series:

Social Sciences, Education and Humanities (GCSSSEH), Volume 6, 2020

International Conference Fakultas Tarbiyah dan Keguruan Universitas Islam Negeri Imam Bonjol

Padang (ICFTKUINIBP) 2019

DOI: https://doi.org/10.32698/GCS-PSSHERS346

\title{
The Influence of Puzzle Picture Games Media in Improving Learning Outcomes in Thematic Learning in Class IV MIN, Solok City
}

\section{Pengaruh Media Games Puzzle Picture Dalam Meningkatkan Hasil Belajar Pada Pembelajaran Tematik Di Kelas IV MIN Kota Solok}

\author{
Syahril $^{\text {a }}$, Fransiska Roza Linda ${ }^{\text {a }}$ \\ ${ }^{a}$ Universitas Islam Negeri Imam Bonjol, Padang, Indonesia \\ E-mail: syahril@uinib.ac.id
}

\begin{abstract}
This research is motivated by thematic learning at MIN Kota Solok which is still dominated by educators, and has not been supported by interesting learning media. In learning, students have not been able to analyze, answer, and make conclusions from the material being studied. Based on the preliminary study, there were only $36 \%$ of students whose scores met the KKM. This study aims to improve the learning outcomes of class IV students of MIN Kota Solok through the Puzzle Picture Games media. The subjects of this study were all students of class IV MIN Kota Solok, totaling 30 students. This research is a quasy experimental study using a one group pretest posted design. The results (pretest) in class IV MIN Kota Solok obtained 13 students reached the KKM and 17 students did not reach the KKM with an average value of 76.00 , if as a percentage of the results from the pretest only $43 \%$ reached the KKM, 57\% did not reach the KKM. While the results after the treatment (posttest) in class IV MIN Kota Solok obtained 25 students who reached the KKM and 5 students who did not reach the KKM with an average of 83.33. If a percentage of the results from the posttest $83 \%$ of students reached the KKM and 27\% did not reach the KKM. Data analysis was performed using t test and obtained thit 7,191>t table 2,045 so that it was concluded that tcount $>t$ table $(7,191>2,045)$. This means that the change in student learning outcomes between the pretest and posttest is very significant.
\end{abstract}

Keywords: Thematic, picture puzzle media, learning outcomes

\section{PENDAHULUAN}

Dalam Peraturan Pemerintah Nomor 32 Tahun 2013 Pasal 19 ayat 1 mengemukakan bahwa proses pendidikan pada satuan pendidikan diselenggarakan secara interaktif, inspiratif, menyenangkan, menantang, memotivasi peserta didik untuk berpartisipasi aktif, serta memberikan ruang yang cukup bagi prakarsa, kreativitas dan kemandirian sesuai dengan bakat, minat dan perkembangan fisik serta psikologis peserta didik. Selanjutnya dalam Permendikbud Nomor 103 Tahun 2014 tentang Pembelajaran pada Pendidikan Dasar dan Menengah Pasal 2 mengemukakan bahwa (1) Pembelajaran dilaksanakan berbasis aktivitas dengan karakteristik: (a) interaktif dan inspiratif, (b) menyenangkan, menantang dan memotivasi peserta didik untuk berpartisipasi aktif, (c) kontekstual dan kolaboratif, (d) memberikan ruang yang cukup bagi prakarsa, kreativitas dan kemandirian peserta didik dan (e) sesuai dengan bakat, minat, kemanpuan dan perkembangan fisik serta psikologis peserta didik. Maka untuk merealisasikan Peraturan Pemerintah dan Permendikbud di atas dituntut memiliki keterampilan dalam menggunakan model, pendekatan, strategi, metode serta media pembelajaran yang dapat meningkatkan motivasi dan hasil belajar peserta didik.

Media pembelajaran merupakan seluruh alat dan bahan yang dipakai untuk tujuan pendidikan, seperti radio, televisi, buku, Koran, majalah dan sebagainya.( Wina Sanjaya : 2008) Adanya media sekaligus sebagai sumber belajar sangat membantu peserta didik untuk mencapai tujuan pembelajaran.Dengan demikian, media jelas diperlukan, sebab media pengajaran mempunyai peran yang besar dan berpengaruh terhadap pencapaian tujuan pendidikan yang diinginkan.

Ada banyak media yang dapat dimanfaatkan oleh pendidik dalam pembelajaran.Diantaranya adalah media Games Picture Puzzle.Penggunaan media games puzzle picture lebih menekankan pada keterlibatan

Copyright (C) 2020, the Authors. Published by Redwhite Press.

Page | 321

This is an open access article under the CC BY-NC license

(http://creativecommons.org/licenses/by-nc/4.0). 
peserta didik dalam proses belajar secara aktif dalam proses pembelajaran, sehingga peserta didik dapat memperoleh pengalaman langsung dan terlatih untuk dapat menemukan berbagai pengetahuan yang dipelajarinya. (Slamet Arifin : 2008) melalui media ini akanmemungkinkan adanya partisipasi aktif dari peserta didikdalam pembelajaran, sehingga akan meningkatkan hasil belajar peserta didik. Belajar yang baik adalah belajar yang aktif. Permainan akanmelibatkan peserta didik dalam pembelajaran secara aktif.

( Sadiman : 2014)

Rahmanelli mengemukakan bahwa media puzzle merupakan media permainan merangkai potonganpotongan gambar yang berantakan menjadi gambar yang utuh. ( Rahmaneli : 2007) Media ini disajikan sebagai salah satu acuan bagi pengajar yang bervariasi dalam proses mengajar. Hal tersebut dilakukan agar siswa lebih aktif dalam kegiatan pembelajaran, sehingga dapat meningkatkan hasil belajar peserta didik. Dalam pembelajaran yang menggunakan media games puzzle picture peserta didik dapat menyusun beberapa potongan-potongan gambar yang dapat melatih peserta didik dalam menganalisa dan mengingat materimateri yang disampaikan pendidik. Media games puzzle picture ini berbasis visual. Media visual merupakan penyampaian pesan atau informasi secara teknik dan kreatif yang mana menampilkan gambar, grafik serta tata dan letaknya jelas.( Ani Rosidah : 2017) Media visual dapat memperlancar pemahaman dan memperkuatingatan.Visual dapat pula menumbuhkan minat peserta didik dan dapatmemberikan hubungan antara isi materi pelajaran dengan dunia nyata. (Azhar Arsyad : 2016)

Berdasarkan observasi awal yang dilaksanakan peneliti di MIN Kota Solok, dalam pembelajaran tematik pendidik sudah menerapkan pendekatan scientific. Namun, belum didukung oleh media pembelajaran yang menarik. MIN Kota Solok sudah menyediakan media Infocus. Akan tetapi, belum digunakan sepenuhnya oleh pendidik dalam mengimplementasikan tema-tema berdasarkan kurikulum 2013. Media pembelajaran yang sudah terintegrasi dengan kurikulum 2013 adalah modul tematik yang diperoleh dari pemerintah.Modul tematik berisi berbagai mata pelajaran yang berkaitan dengan tema.Sedangkan dalam pembelajaran, pendidik lebih sering terpusat atau mengacu pada modul tematik saja.Kelemahan dari modul tematik adalah materi yang dijelaskan atau dipaparkan kurang jelas.Sehingga peserta didik belum sepenuhnya mampu menganalisisi pertanyaan-pertanyaan yang diberikan oleh pendidik, belum sepenuhnya mampu untuk menjawab pertanyaan dan membuat kesimpulan dari pembelajaran yang telah diajarkan. Nilai tematik terkait peserta didik kelas IV MIN Kota Solok masih berada di bawah KKM, dimana KKM nilai yang ditetapkan adalah 80,00. Hal itu disebabkan oleh pemahaman peserta didik yang masih kurang terhadap materi yang diajarkan, dan pembelajaran tematik cenderung mencatat rangkuman yang diberikan oleh pendidik, sehingga peserta didik menjadi pasif selama proses pembelajaran.

Dari 30 peserta didik hanya 11 peserta didik yang tuntas dan 19 peserta didik belum tuntas.Jika dipersentasekan yang tuntas hanya $37 \%$ dari $100 \%$. Hal ini secara klasikal dapat dinyatakan bahwa pembelajaran masih belum tuntas. Untuk membuat peserta didik antusias dalam pembelajaran tematik, maka diperlukan pendidik yang kreatif dan inovatif yang dapat memilih serta menggunakan media pembelajaran yang baik dan sesuai dengan karakteristik peserta didik, sehingga pembelajaran dapat terlaksana dengan menyenangkan.Untukmengatasi permasalahan pembelajaran di atas, penelitian ini ingin melihat pengaruh penggunaan media games pazzle picture dalam meningkatkan hasil belajar peserta didik kelas IV MIN Kota Solok pada pembelajaran tematik sesuai dengan kurikulum 2013.

\section{METODOE}

Penelitian ini menggunakan penelitian eksperimen semu (Quasi Experiment)tipe one-group pretest and posttest design yang dilaksanakan pada satu kelompok tanpa kelompok pembanding. One Group Pretest Posttest Design adalah salah satu desaineksperimen semu yang mana dilakukan pretest untuk mengetahuikemampuan peserta sebelum perlakuan diberikan. Setelah itu dilakukantreatment dengan menggunakan media games puzzle picture dalampembelajaran Tematik. Setelah treatment, dilakukanposttest untuk mengetahui hasil belajar peserta didik.Populasi pada penelitian adalah seluruh peserta didik kelas IV MIN Kota Solok yang berjumlah 30 peserta didik.

\section{PEMBAHASAN \\ Deskripsi Data}

Berdasarkan penelitian yang telah dilakukan pada Kelas IV MIN Kota Solok, maka diperoleh data hasil belajar Tematik. Peserta didik diberi tes awal (pretest) pada pokok bahasan, keragaman social, ekonomi, budaya, etnis, dan agama di provinsi setempat (IPS) dan kerjasama dalam keberagaman social, ekonomi, 
budaya (PPKn). Sebelum pembelajaran dengan media games puzzle picture diberikan kepada peserta didik, terlebih dahulu diinformasikan kepada peserta didik mengenai pokok bahasan yang akan dipelajari.

Jumlah soal pretest dan posttest yang diberikan sebanyak 20 (dua puluh) butir soal, yang terdiri dari 10 objektif, 5 isian, dan 5 essay.Soal pretest dapat dilihat pada lampiran.Setelah hasil pretest dan posttest diperoleh selanjutnya dilakukan perhitungan rata-rata kelas pada nilai pretest dan posttest.Dari perolehan nilai pretest dan posttest peserta didik tersebut dapat dilihat kemampuan peserta didik dalam memahami materi yang dipelajari. Adapun nilai pretest dan posttest table berikut:

Tabel 1. Hasil Pretest dan Postest Kelas IV MIN Kota Solok

\begin{tabular}{|c|c|c|c|c|}
\hline \multirow[t]{2}{*}{ NO } & \multirow[t]{2}{*}{ NAMA } & \multicolumn{3}{|c|}{ NILAI } \\
\hline & & PRETEST & POSTEST & \\
\hline 1 & $\mathrm{AH}$ & 81 & 86 & \\
\hline 2 & $\mathrm{AA}$ & 52 & 78 & \\
\hline 3 & AR & 79 & 82 & \\
\hline 4 & AS & 70 & 79 & \\
\hline 5 & $\mathrm{BA}$ & 76 & 86 & \\
\hline 6 & $\mathrm{DA}$ & 70 & 72 & \\
\hline 7 & FJ & 74 & 86 & \\
\hline 8 & $\mathrm{FN}$ & 81 & 94 & \\
\hline 9 & $\mathrm{HA}$ & 84 & 90 & \\
\hline 10 & IN & 72 & 84 & \\
\hline 11 & $\mathrm{KP}$ & 86 & 88 & \\
\hline 12 & MA & 78 & 84 & \\
\hline 13 & $\mathrm{MN}$ & 80 & 80 & \\
\hline 14 & MV & 76 & 82 & \\
\hline 15 & $\mathrm{MF}$ & 86 & 88 & \\
\hline 16 & $\mathrm{MF}$ & 80 & 93 & \\
\hline 17 & NR & 78 & 88 & \\
\hline 18 & NE & 64 & 80 & \\
\hline 19 & NF & 75 & 84 & \\
\hline 20 & QS & 86 & 88 & \\
\hline 21 & $\mathrm{RF}$ & 76 & 82 & \\
\hline 22 & $\mathrm{RN}$ & 56 & 58 & \\
\hline 23 & $\mathrm{RG}$ & 86 & 90 & \\
\hline 24 & $\mathrm{RS}$ & 80 & 90 & \\
\hline 25 & SA & 76 & 80 & \\
\hline 26 & SK & 72 & 84 & \\
\hline 27 & VS & 84 & 86 & \\
\hline 28 & VA & 80 & 82 & \\
\hline 29 & ZR & 82 & 86 & \\
\hline 30 & ZW & 60 & 70 & \\
\hline & Jumlah & 2.280 & & 2.500 \\
\hline & Rata-Rata & 76.00 & & 83.33 \\
\hline & Ketuntasan & $43 \%$ & & $83 \%$ \\
\hline
\end{tabular}

Data tabel di atas, menunjukkan hasil sebelum diberikannyaperlakuan (pretest) di kelas IV MIN Kota Solok diperoleh 13 peserta didikmencapai KKM dan 17 peserta didik tidak mencapai KKM dengan rataratanilai 76.00, jika dipersentasekan hasil dari pretest hanya $43 \%$ yang tuntas,57\%tidak tuntas. Sedangkan hasil sesudah diberikannya perlakukan(posttest) diperoleh sebanyak 25 peserta didik yangmencapai KKM dan 5 peserta didik yang tidak mencapai KKM dengan ratarata 83.33. jika dipersentasekan hasil dari posttest 
83\% peserta didikmencapai KKM dan 17\% tidak mencapai KKM. Berdasarkan nilai rata-ratadan persentase dari pretest dan posttest di atas dapat dilihat perbedaanpencapaian hasil belajar peserta didik yang sangat jauh.

\section{Analisis Tes Uji Coba}

Setelah soal tersebut diuji cobakan, kemudian dilakukan analisis item soal untuk melihat baik atau tidaknya suatu tes. Analisis soal antara lain bertujuan untuk mengadakan identifikasi soal yang baik, kurang baik dan jelek. Dengan analisis soal dapat diperoleh baik atau tidaknya sebuah soal dengan petunjuk untuk mengadakan perbaikan.

\section{Validitas Tes}

Dari 25 soal uji coba dianalisis melalui Microsoft Excel. Terdapat 20 dan terdapat terdapat 5 soal yang tidak valid yaitu soal nomor $6,11,15,18$, dan 25sebagaimana data pada tabel 2 .

\section{Daya Beda}

Tabel 2. Daya Beda Soal

\begin{tabular}{ccccccll}
\hline $\mathbf{N 0}$ & $\mathbf{B}_{\mathbf{a}}$ & $\mathbf{B}_{\mathbf{b}}$ & $\mathbf{J A}$ & $\mathbf{J B}$ & $\mathbf{D}$ & \multicolumn{1}{c}{ KRITERIA } & KET \\
\hline $\mathbf{1}$ & 12 & 7 & 15 & 6 & 0,55 & Baik & Terima \\
$\mathbf{2}$ & 12 & 5 & 15 & 6 & 0,77 & Baik sekali & Terima \\
$\mathbf{3}$ & 13 & 6 & 15 & 6 & 0,77 & Baik & Terima \\
$\mathbf{4}$ & 9 & 5 & 15 & 6 & 0,44 & Baik & Terima \\
$\mathbf{5}$ & 13 & 5 & 15 & 6 & 0,88 & Baik sekali & Terima \\
$\mathbf{6}$ & 3 & 2 & 15 & 6 & 0,11 & Jelek & Buang \\
$\mathbf{7}$ & 11 & 8 & 15 & 6 & 0,77 & Baik sekali & Terima \\
$\mathbf{8}$ & 12 & 8 & 15 & 6 & 0,66 & Baik & Terima \\
$\mathbf{9}$ & 12 & 6 & 15 & 6 & 0,66 & Baik & Terima \\
$\mathbf{1 0}$ & 10 & 4 & 15 & 6 & 0,66 & Baik & Terima \\
$\mathbf{1 1}$ & 6 & 6 & 15 & 6 & 0 & Jelek & Buang \\
$\mathbf{1 2}$ & 13 & 6 & 15 & 6 & 0,77 & Baik sekali & Terima \\
$\mathbf{1 3}$ & 10 & 4 & 15 & 6 & 0,66 & Baik & Terima \\
$\mathbf{1 4}$ & 13 & 7 & 15 & 6 & 0,66 & Baik & Terima \\
$\mathbf{1 5}$ & 3 & 2 & 15 & 6 & 0,11 & Jelek & Buang \\
$\mathbf{1 6}$ & 10 & 7 & 15 & 6 & 0,33 & Cukup & Terima \\
$\mathbf{1 7}$ & 14 & 6 & 15 & 6 & 0,88 & Baik sekali & Terima \\
$\mathbf{1 8}$ & 2 & 1 & 15 & 6 & 0,11 & Jelek & Buang \\
$\mathbf{1 9}$ & 11 & 8 & 15 & 6 & 0,77 & Baik sekali & Terima \\
$\mathbf{2 0}$ & 10 & 7 & 15 & 6 & 0,33 & Cukup & Terima \\
$\mathbf{2 1}$ & 12 & 5 & 15 & 6 & 0,77 & Baik sekali & Terima \\
$\mathbf{2 2}$ & 14 & 5 & 15 & 6 & 1 & Baik sekali & Terima \\
$\mathbf{2 3}$ & 11 & 6 & 15 & 6 & 0,55 & Baik & Terima \\
$\mathbf{2 4}$ & 9 & 5 & 15 & 6 & 0,44 & Baik & Buang \\
$\mathbf{2 5}$ & 4 & 3 & 15 & 6 & 0,11 & Jelek & \\
\hline & & & & & & & 6 \\
\hline
\end{tabular}

Berdasarkan hasil perhitungan dari tabel 2 diketahui bahwa terdapat 8 soal dalam kategori daya beda baik sekali, 9 soal dalam kategori kategori daya pembeda baik, 2 soal dalam kategori cukup .dan 5 soal dalam kategori daya beda jelek. Dalam hal ini, peneliti untuk tidak memakai soal kategori jelek pada soal yang akan di-posttest-kan pada peserta didik kelas IV MIN Kota Solok.

\section{Indeks Kesukaran}

Indeks Bilangan yang menunjukkan sukar dan mudahnya sesuatu soal disebut indeks kesukaran (Suharsimi Arikunto :2005) 
Tabel 3. Indeks Kesukaran

\begin{tabular}{ccccl}
\hline N0 & B & JS & P & KRITERIA \\
\hline $\mathbf{1}$ & 19 & 21 & 1 & Mudah \\
$\mathbf{2}$ & 17 & 21 & 0,85 & Mudah \\
$\mathbf{3}$ & 19 & 21 & 1 & Mudah \\
$\mathbf{4}$ & 14 & 21 & 0,76 & Mudah \\
$\mathbf{5}$ & 18 & 21 & 1 & Mudah \\
$\mathbf{6}$ & 5 & 21 & 0,23 & Sulit \\
$\mathbf{7}$ & 19 & 21 & 0,95 & Mudah \\
$\mathbf{8}$ & 20 & 21 & 1 & Mudah \\
$\mathbf{9}$ & 17 & 21 & 0.80 & Mudah \\
$\mathbf{1 0}$ & 14 & 21 & 0,76 & Mudah \\
$\mathbf{1 1}$ & 12 & 21 & 0,47 & Sedang \\
$\mathbf{1 2}$ & 19 & 21 & 0,90 & Mudah \\
$\mathbf{1 3}$ & 14 & 21 & 0,76 & Mudah \\
$\mathbf{1 4}$ & 20 & 21 & 1 & Mudah \\
$\mathbf{1 5}$ & 4 & 21 & 0,23 & Sulit \\
$\mathbf{1 6}$ & 17 & 21 & 0,85 & Mudah \\
$\mathbf{1 7}$ & 20 & 21 & 1 & Mudah \\
$\mathbf{1 8}$ & 3 & 21 & 0,04 & Sulit \\
$\mathbf{1 9}$ & 19 & 21 & 1 & Mudah \\
$\mathbf{2 0}$ & 17 & 21 & 0,80 & Mudah \\
$\mathbf{2 1}$ & 17 & 21 & 0,85 & Mudah \\
$\mathbf{2 2}$ & 19 & 21 & 0,76 & Mudah \\
$\mathbf{2 3}$ & 17 & 21 & 0,90 & Mudah \\
$\mathbf{2 4}$ & 14 & 21 & 0,76 & Mudah \\
$\mathbf{2 5}$ & 6 & 21 & 0,28 & Sulit \\
\hline
\end{tabular}

Berdasarkan hasil perhitungan di atas diketahui bahwa terdapat 20 soal dalam termasuk kategori soal mudah karena berada pada rentang indek kesukaran mudah, 1 soal dalam kategori sedang dan 4 soal dalam kategori sulit.

\section{Uji Reliabilitas} berikut :

Berdasarkan perhitungan menggunakan Microsoft Excel diperoleh koefisien Reliabilitas sebagai

Reliabilitas tes objektif dan isian adalah 0,692 . Pada $\alpha=5 \%$ dengan $n=21$ diperoleh $\mathrm{r}_{\text {tabel }}=0,413$. Karena r11 > rtabel $(0,692>0,413)$ maka soal objektif dan isian dinyatakan reliable.

Reliabilitas tes essay adalah 0,487 . Pada $\alpha=5 \%$ dengan $n=21$ diperoleh rtabel $=0,413$. Karena $\mathrm{r} 11>$ rtabel $(0,487>0,413)$ maka soal essay dinyatakan reliable

\section{Analisis Data}

Analisis data dilakukan untuk mengetahui kemampuan peserta didik di kelas IV MIN Kota Solok sejalan dengan rancangan penelitian yang telah dikemukakan sebelumnya.Sesuai dengan Kurikulum 2013 dalam hasil belajar harus mencakup 3 ranah, yaitu ranah afektif, ranah psikomotor dan ranah kognitif.

\section{Ranah Afektif}

Data untuk ranah afektif ini diperoleh berdasarkan catatan pada lembar observasi terhadap sikap peserta didik selama pembelajaran berlangsung pada setiap pertemuan. Penilaian afektif meliputi dua aspek, yaitu bekerjasama dan juga mau menghargai antar peserta didik dan juga pendidik.

\section{Sikap Kerja Sama}

Karakter kerjasama dapat ditanamkan, dilatih, dan dikembangkan melalui berbagai cara, salah santu bentuknya melalui kegiatan pembelajaran. Kerjasama dalam pembelajaran dapat dilakukan oleh dua siswa atau lebih yang saling berinteraksi, menggabungkan tenaga, ide atau pendapat dalam waktu tertentu dalam mencapai tujuan pembelajaran sebagai kepentingan bersama. (Silvi Dwi Yulianti : 2005) Observasi 
dilakukan saat kegiatan pembelajaran berlangsungdengan menggunakan indikator kerjasama yang terdiri dari :(a). terlibat aktif dalam kelompok, (b). kesediaan melakukan tugas sesuai kesepakatan, (c). bersedia membantu orang lain dalam satu kelompok yang mengalami kesulitan, (d). rela berkorban untuk teman lain dan (e) . tidak bekerja sesuai kehendak sendiri.

\section{Sikap Menghargai}

Pendidikan Karakter disekolah merupakan pembelajaran yang mengarah pada pengembangan dan penguatan perilaku anak secara utuh, didasarkan suatu nilai tertentukemudian dirujuk oleh sekolah. ( Kesuma : 2011) Saling menghargai adalah sikap memperlakukan orang lain seperti keinginan ingin dihargai, beradab, sopan, dan tidak melecehkan ataupun menghina orang lain. (Samani “ 2011) Observasi dilakukan saat kegiatan pembelajaran berlangsung dengan menggunakan indikator menghargai yang terdiri dari: (a). menerima perbedaan pendapat, (b). mengakui kelebihan orang lain, (c). tidak menghina orang lain, (d). memaklumi kekurangan orang lain, dan (e). menghargai pendidik.

Dari empat kali pertemuan, berdasarkan indikator di atas didapat data penilaian sikap sebagaimana tergambar dalam table berikut:

Tabel 4. Hasil Penilaian Sikap

\begin{tabular}{cccc}
\hline PERTEMUAN & KERJASAMA & MENGHARGAI & PREDIKET \\
\hline I & 74,66 & 79,33 & $\mathrm{~B}$ \\
II & 80,66 & 81,33 & $\mathrm{~A}$ \\
III & 82 & 86 & $\mathrm{~A}$ \\
IV & 89,33 & 97,33 & $\mathrm{~A}$ \\
\hline
\end{tabular}

Skor Penilaian
$80-100 \quad$ : A: Sangat Baik
$50-79 \quad$ : B : Baik
$049:$ C : Cukup

Dari table di atas terlihat bahwa setiap pertemuan mengalami peningkatan terhadap sikap kerjasama dan sikap menghargai dari peserta didik kelas IV MIN Kota Solok.

\section{Ranah Psikomotor}

Data untuk ranah psikomotor ini diperoleh berdasarkan catatan pada lembar observasi terhadap keterampilan peserta didik selama pembelajaran berlangsung pada setiap pertemuan. Penilaian pskomotor meliputi dua aspek, yaitu keterampilan berkomunikasi dan juga keterampilan mendengakan, baik mendengarkan penyampaian materi oleh pendidik maupun mendengarkan persentasi dari kelompok lain.

Adapun ranah psikomotor yang dilihat dalam penelitian ini adalah keterampilan berkomunikasi dan keterampilan mendengarkan.Pentingnya teknik mendengar secara baik dalam komunikasi, agar pelaku komunikasi dapat menciptakan komunikasi yang efektif.Indikator Keterampialan berkomunikasi terdiri dari keterampilan (a).mempresentasikan hasil diskusi, (b) menyampaikan pendapat, (c) tata bahasa yang baik, (d) menjawab pertanyaan dengan baik, dan (e) pembicaraan jelas dan mudah dimengerti. Sedangkan indikator keterampilan mendengarkan terdiri dari (a) mendengarkan pembicaraan dengan penuh konsentrasi, (b) meyakinkan diri bahwa isi pembicaraan dikelas perlu, (c).merespon apa yang dikatakan lawan pembicara, d). mendengar pembicaraan dengan rasa suka dan (e) bertanya mengenai sesuatu yang belum jelas.

Berdasarkan kedua aspek tersebut, secara keseluruhan dapat dikatakan bahwa setiap pertemuan nilai sikap dari kelas IV MIN Kota Solok meningkat. Peningkatan itu dapat dilihat pada table berikut:

Tabel 5. Hasil Penilaian Aspek Keterampilan

\begin{tabular}{cccc}
\hline PERTEMUAN & KOMUNIKASI & MENDENGAR & PREDIKET \\
\hline I & 62,66 & 67,33 & $\mathrm{~B}$ \\
II & 74,66 & 77,33 & $\mathrm{~B}$ \\
III & 81,33 & 84 & $\mathrm{~A}$ \\
IV & 92 & 94,66 & $\mathrm{~A}$ \\
\hline
\end{tabular}

Skor Penilaian

80-100 : A: Sangat Baik

50-79 : B : Baik

$049 \quad$ : C : Cukup 
Dilihat dari tabel di atas terlihat setiap pertemuan mengalami peningkatan terhadap keterampilan berkomunikasi dan keterampilan mendengar dari peserta didik kelas IV MIN Kota Solok.

\section{Ranah Kognitif}

Untuk menganalisis data tersebut menggunakan uji-t.analisis data hasil belajar tematik peserta didik dapat dilakukan dengan cara sebagai berikut :

a. Menentukan Selisih Nilai Rata-Rata Pretest dan Posttest

Perbedaan nilai dan rata-rata pretest dan posttest dapat dilihat pada tabel berikut:

Tabel 6. Perbedaan Nilai dan Rata-Rata Pretest dan Posttest

\begin{tabular}{|c|c|c|c|c|c|c|c|c|}
\hline & & $\mathbf{N}$ & Range & $\begin{array}{l}\text { Mini } \\
\text { Mum }\end{array}$ & $\begin{array}{l}\text { Maxi } \\
\text { mum }\end{array}$ & Sum & Mean & Std. Deviation \\
\hline Pretest & & 30 & 34 & 52 & 86 & 2280 & 76.00 & 8.670 \\
\hline Postest & & 30 & 36 & 58 & 94 & 2500 & 83.33 & 7.194 \\
\hline $\begin{array}{l}\text { Valid } \\
\text { (listwise) }\end{array}$ & $\mathbf{N}$ & 30 & & & & & & \\
\hline
\end{tabular}

Dari tabel di atas dapat dilihat bahwa terdapat peningkatan nilai rata-rata antara pretest dan posttest dengan selisih antara pretest sebesar 76.00 dengan posttest 83.33. Dengan demikian dapat disimpulkan bahwa terdapat pengaruh hasil belajar peserta didik kelas IV MIN Kota Solok pada tema Indahnya Kebersamaan dengan materi keragaman sosial, ekonomi, budaya, etnis, dan agama di provinsi setempat dan kerjasama dalam keberagaman sosial, ekonomi, budaya dengan menerapkan media Games Puzzle Picture sangatlah meningkat.

b. Uji Normalitas Data

Uji normalitas ini bertujuan untuk mengetahui apakah data pretest dan posttest berdistribusi normal atau tidak. Data yang digunakan adalah data pretest dan posttest. Data dikatakan berdistribusi normal jika nilai signifikansinya $>0.025$. Data yang dihasilkan digunakan sebagai pengujian prasyarat analisis hasil belajar.Pengujian ini dilakukan sebagai pengujian prasyarat analisis hasil belajar. Pengujian ini dilakukan dengan bantuan program SPSS for windows version 20. Berikut ini hasil pengujian normalitas hasil belajar pretest dan posttest.

Tabel 7. Hasil Pengujian Normalitas Hasil Belajar Pretest dan Posttest

\begin{tabular}{llrr}
\hline & & Pretest & Posttest \\
\hline $\mathbf{N}$ & & 30 & 30 \\
Normal & Mean & 76.00 & 83.33 \\
Parameters, & Std. Deviation & 8.670 & 7.194 \\
Most Extreme & Absolute & .167 & .160 \\
Differences & Positive & .124 & .110 \\
Kolmogorov-Smirnov Z & Negative & -.167 & -.160 \\
Asymp. Sig. (2-tailed) & & .913 & .875 \\
& & .375 & .428 \\
\hline
\end{tabular}

a. Test distribution is Normal.

b. Calculated from data.

Salah satu prasyarat uji t (paired sample t test) adalah asumsi normalitas data.Berdasarkan uji kolmogorov smirnov pada tabel di atas diperoleh nilai signifikansi untuk nilai pretest sebesar 0.375 dan nilai posttest sebesar 0.428 . Kedua nilai tersebut lebih besar dari nilai alpha (5\%). Maka Data telah berdistribusi normal.

c. Uji Homogenitas Data

Uji homogenitas ini bertujan untuk mengetahui data pretest dan posttest mempunyai varians yang sama atau tidak. Pengujian inidilakukan karena telah diketahui bahwa data berdistribusi normalberdasarkan pengujian normalitas. Data dikatakan homogen jikamempunyai nilai signifikan . 0.025. Berikut analisis uji homogrnitasmengguanakan program SPSS 20. 
Tabel 8. Uji Homogenitas DataTest of Homogeneity of Variances Nlai Pretest dan Posttest

\begin{tabular}{llclll}
\hline Levene Statistic & & df1 & df2 & Sig. \\
\hline & $\mathbf{8 9 5}$ & & 1 & 58 & .348 \\
\hline
\end{tabular}

Berdasarkan hasil belajar pretest dan posttest adalah homogen.Hal itu ditunjukkan dengan nilai sig sebesar 0.348 yang artinya lebih besar dari 0.025 . Jadi dapat disimpulkan bahwa H0 ditolak dan H1 diterima, yang berarti hasil belajar pretest dan posttest mempunyai varians yang sama.

d. Uji Hipotesis

Hipotesis yang di uji dalam penelitian ini menggunakan analisis paired sample t test adalah:

$\mathrm{H}_{0}=\quad$ Tidak terdapat pengaruh yang signifikan penggunaan media pembelajaran Games Puzzle Picture pada tema Indahnya Kebersamaan terhadap hasil belajar Peserta didik di kelas IV MIN Kota Solok.

$\mathrm{H}_{1}=\quad$ Terdapat pengaruh yang signifikan penggunaan media pembelajaran Games Puzzle Picture pada tema Indahnya Kebersamaan terhadap hasil belajar Peserta didik di kelas IV MIN Kota Solok.

$\mathrm{H}_{0}=$ Hipotesis Nihil

$\mathrm{H}_{1}=$ Hipotesis Alternatif

Df $=\mathrm{N}-1$, dengan Df sebesar 30-1 = 29 diperoleh harga kritik t pada tabel sebagai berikut: Pada taraf signifikasi $5 \%: t_{1}=2,045$. Kriteria uji:Nilai signifikansi <a (0.025) atau nilai -t hitung < $\mathrm{t}_{\text {tabel }}$ maka tolak H. Uji paired sample $t$ test diakukan menggunakan bantuan software SPSS, berikut output SPSS:

e. Uji N-Gain

Pada analisis uji N-gain diperoleh hasil, sebagai berikut :

$$
\underset{9-7.01 .0}{\mathrm{~g}=} \underline{\frac{8.3-7.0}{1.0}}=\underline{7.3}=0.40
$$

Perhitungan $\mathrm{N}$-gain dari hasil pretest dan posttest terdapat $\mathrm{N}$-gain sebesar 0.40 . Jadi, kriteria perhitungan $\mathrm{N}$-gain terletak pada rentang $0.3 \leq \mathrm{g}<0.7$ dengan kriteria sedang.

$U j i-T$

Kriteria pengambilan keputusan jika nilai signifikasi > 0,025 maka hipotesis H0 diterima dan H1 ditolak. Sebaliknya, jika nilai signifikasi < 0,025 maka H0 ditolak dan H1diterima.

\begin{tabular}{|c|c|c|c|c|c|c|c|c|c|}
\hline & & \multicolumn{5}{|c|}{ Paired Differences } & \multirow[t]{2}{*}{$\mathbf{T}$} & \multirow[t]{2}{*}{ df } & \multirow{2}{*}{$\begin{array}{c}\text { Sig. } \\
\text { (2-tailed) }\end{array}$} \\
\hline & & Mean & $\begin{array}{c}\text { Std. } \\
\text { Deviation }\end{array}$ & $\begin{array}{l}\text { Std. } \\
\text { Error } \\
\text { Mean }\end{array}$ & \multicolumn{2}{|c|}{$\begin{array}{l}95 \% \text { Confidence } \\
\text { Interval of the } \\
\text { Difference }\end{array}$} & & & \\
\hline $\begin{array}{c}\text { Pair } \\
1\end{array}$ & $\begin{array}{l}\text { Posttest } \\
\text { Pretest }\end{array}$ & 7.333 & 5.585 & 1.020 & $\begin{array}{c}\text { Lower } \\
9.419\end{array}$ & $\begin{array}{l}\text { Upper } \\
5.248\end{array}$ & 7.191 & 29 & .000 \\
\hline
\end{tabular}
Tabel 9. Uji Hipotesis Paired Samples Test Uji t Paired Samples Test

Berdasarkan tabel di atas diketahui bahwa nilai signifikansi sebesar 0.000 lebih kecil dari 0.025.nilai t hitung sebesar $7.191>\mathrm{t}$ tabel 2.045. Maka Tolak H0 . Artinya Terdapat pengaruh yang signifikan media pembelajaran Games Puzzle Picture pada tema Indahnya Kebersamaan terhadap Hasil Belajar Peserta didik di kelas IV MIN Kota Solok.

Kesimpulan dapat ditarik antara skor hasil tes Tematik sebelum perlakuan (pretest) dan sesudah perlakuan (posttest) dilaksanakan pada tes IPS dan PPKn, terdapat peningkatan yang signifikansi. Ini mengandung makna, bahwa pelaksanaan pembelajaran Media Games Puzzle Picture telah berhasil membantu proses belajar peserta didik kelas IV MIN Kota Solok. 
Dalam meningkatkan kemampuan memahami materi keragaman social, ekonomi, budaya, etnis, dan agama di provinsi setempat (IPS) dan kerjasama dalam ke beragaman social, ekonomi, budaya (PPKn). Nilai Tematik mereka sangat signifikansi meningkat atau lebih baik jika dibandingkan sebelum mengikuti program tes.

\section{SIMPULAN}

Media games puzzle picture merupakan media permainan merangkai potongan potongan gambar yang berantakan menjadi gambar yang utuh. Media sebagai ini disajikan sebagai salah satu acuan bagi pengajar yang bervariasi dalam proses mengajar. Hal tersebut dilakukan agar siswa lebih aktif dalam kegiatan pembelajaran, sehingga dapat meningkatkan hasil belajar peserta didik, baik dari segi aspek kognitif, afentif maupun psikomotor. Dalam pembelajaran yang menggunakan media games puzzle picture peserta didik dapat menyusun beberapa potongan-potongan gambar yang dapat melatih peserta didik dalam menganalisa dan mengingat materi-materi yang disampaikan pendidik. Melalui media puzzle peserta didik tidak hanya untuk bermain tetapi juga mengasah otak dan melatihantara kecepatan pikiran dan tantangan.Berdasarkan pemaparan di atas, dapat disimpulkan bahwa penggunaanMedia Games Puzzle Picture berpengaruh signifikan terhadap hasil belajarpeserta didik pada pembelajaran di kelas IV MIN Kota Solok.

\section{REFERENSI}

Ani Rosidah, Penerapan Media Pembelajaran Visual Untuk Meningkatkan Pemahaman Konsep Siswa Pada Mata Pelajaran IPS, Jurnal Cakrawala Pendas Nomor 2 Volume 2. ISSN 2442-7470

Azhar Arsyad, Media Pembelajaran, (Jakarta : Rajawali Pers, 2016)

Kesuma, Pendidikan Karakter Kajian Teori dan Praktik di Sekolah, (Bandung:Remaja Rosdakarya, 2011)

Kesuma, Pendidikan Karakter Kajian Teori dan Praktik di Sekolah, (Bandung:Remaja Rosdakarya, 2011), h. 5

Mulyasa, Pengembangan dan Implementasi Kurikulum 2013, (Bandung :PT Remaja Rosdakarya, 2013), h. 147

Rahmanelli, Efektivitas Pemberian Tugas Media dalam Pembelajaran Geografi Regional. (Jurnal Pelangi Pendidikan, 2007)

Ramayulis, Samsul Nizar, Filsafat Pendidikan Islam, (Jakarta :KalamMulia, 2009)

Rusman, Pembelajaran Tematik Terpadu. (Jakarta:Rajawali Pers, 2016) -, Pembelajaran Tematik Terpadu. (Jakarta:PT Raja Grafindo Persada:Jakarta, 2015)

Wiwit Nur Ismiati, Penerapan Model Pembelajaan Studen Facilitator And Explaining Untuk Meningkatkan Komunikasi Pada Pembelajran Pada Siswa Sekolah Dasar, Jurnal Didaktika Dwija Indra, ISSN 2337-8786

Sadiman, Media Pendidikan Pengertian, Pengembangan, dan Pemanfaatannya, (Jakarta: Rajawali Pers, 2014)

Samani dkk, Konsep dan Model Pendidikan Karakter, (Bandung: PT Remaja Rosdakarya, 2011)

Slamet Arifin, Pengaruh Pembelajaran Tematik-Integratif Berbasis Sosiokultural Terhadap Hasil Belajar Peserta Didik. Jurnal Profesi Pendidikan Dasar. ISSN 25033530.Volume 3 Nomor 1

Silvy Dwi Yulianti, Pendidikan Karakter Kerjasama Dalam Pembelajaran Siswa Sekolah Dasar Pada Kurikulum 2013, (Universitas Negeri Malang, 2016), Jurnal Teori dan Praksis Pembelajaran IPS ISSN 2503-1201 Vol 1 No 1 April 2016

Sugyono, etode Penelitian Pendidikan(Pendekatan Kuantitatif, Kualitatif, danR\& D), (Bandung : Alfabeta, 2015)

Suharsimi Arikunto, Manajemen Penelitian. (Jakarta:PT Rineka Cipta, 2005)

Wina Sanjaya, Perencanaan \& Desain Sistem Pembelajaran, (Jakarta : Kencana, 2008)

Wiwit Nur Ismiati, Penerapan Model Pembelajaan Studen Facilitator And Explaining Untuk Meningkatkan Komunikasi Pada Pembelajran Pada Siswa Sekolah Dasar, Jurnal Didaktika Dwija Indra, ISSN 2337-8786 